\title{
Ideology and Philosophy in Aristotle's Theory of Slavery
}

\section{Introduction}

Aristotle's views on slavery are an embarrassment to those who otherwise hold his philosophy in high regard. To the modern mind they are morally repugnant. Many find them poorly argued and incompatible with more fundamental tenets of his system, and they certainly contain at least apparent inconsistencies. Worst of all, perhaps, is the suspicion that his theory of slavery is not really philosophy: "Il ne fait de doute pour personne que l'analyse aristotélicienne de l'esclavage - et surtoux les chapitres qu'y consacre le livre I de la Politique - a une fonction idéologique au sens marxiste de mot"'. My paper aims to examine this last claim, and in particular to get clearer about the kinds of evidence which might be offered for or against it, and indeed about what the evidence is evidence of. To my own surprise I conclude that Aristotle's theory is not to any interesting extent ideological.

I operate with a broadly Marxist conception of an ideology, as (i) a widely held body of ideas systematically biased towards the real or imagined interests of a particular sex or social group or class within a society, ${ }^{2}$ (ii) believed by its adherents not because of rational considerations which may be offered in its support but as a result either (a) of social causation or (b) of a desire to promote the interests indicated in (i) (or both). Or to put it more briefly (if more vaguely) a set of "views, ideas, or beliefs that are somehow tainted by the social origin or the social interests of those who held them"4. A philosophical belief, on the other hand, I take to be one which inter alia is held because of the rational considerations which are offered in its support. Thus I make the key difference between ideology and philosophy a question of the causation of the beliefs a thinker holds. ${ }^{5}$ From my formulation it sounds as though the distinction

1 P. Pellegrin, 'La Théorie aristotélicienne d'esclavage: tendances actuelles de l'interprétation', in: Rev. Philosophique (1982), 345-57 (at 350). This paper is the most interesting statement of an ideological interpretation of Aristotle's theory that 1 know of.

2 Cf. e. g. B. Parekh, Marx's Theory of Ideology, London 1982, ch. 2.

3 Cf. e.g. J. Elster, Making Sense of Marx, Cambridge 1985, ch. 8.

4 J. Elster, Karl Marx: a Reader, Cambridge 1986, 299.

3 Historians are often content to label a set of ideas ideological on the basis of (i) alone. 
between rational beliefs and those that are the products of social influences or of ulterior motives is an exclusive one, which would no doubt be a mistake. If it is a mistake, we can expect more or less philosophical ideologies, and more or less ideological philosophies. ${ }^{6}$

Aristotle's theory of slavery perhaps lacks the range or complexity to count as a "body of ideas", although of course the nexus of theses and concepts to which it belongs, e.g. those developed in Pol. $A$ as a whole, clearly does. Nor have I any interest is asking if the theory was "widely held." What I take as obvious, however, is that in all other respects Aristotle's theory does satisfy criterion (i) of ideologies. The question I propose for discussion is: "What explains his belief in the theory?". Is it (e.g. (ii) (a)) one of those "elegantly presented and well-argued theories" that "rest on certain basic assumptions which ... turn out to be uncritical reproductions of the most commonplace beliefs of the ordinary members of [its author's] society or class?"' Is it (cf. (ii) (b)) the work of a partisan "who chose a side, making a primary commitment to a position and defending it with all the weapons of [his] considerable intellectual armoury ?"z In other words, is Aristotle's account of the relation of master and slave as natural anything other than an attempt, deliberate (cf. (ii) (b)) or not (cf. (ii) (a)), to articulate an ideological belief, very likely shared widely among well to do Athenians and Macedonians, that it was right and proper for most masters to be masters and most slaves (especially barbarian slaves) to be slaves? Or is it simply the outcome of purely philosophical reflection?

To think of Aristotle as the victim or accomplice of ideology in his political theory might seem odd to the reader who remembers the treatment of justice in Book $\Gamma$. That discussion gives grounds for seeing Aristotle as himself the first thinker ever to have identified a set of beliefs as an ideology; or at least - to put the point less anachronistically and in a more appropriately down to earth style - he was the first writer we know of

This is no doubt because where such a body of ideas is widely held in a society, it is genThis is no doubt because where such a body of ideas is widely held in a to assume that (ii) provides the best explanation of the phenomenon. - Among English-speaking students of ancient Greek philosophy there has been little discussion of this kind of question. For some pioneering work see G.E. R. Lloyd, Science, Folklore and Ideology, Cambridge 1983 and M. Frede, Essays in Ancient Philosophy, Minneapolis 1987, in his introductory chapter. In his commentary on this paper at Friedrichshafen Charles Kahn questioned the viability of a definition of ideology in terms of the causation of belief. He would prefer to locate our problem within the theory of interpreta tion and to "think of ideology as identifying one particular mode of the more general apcan proach that we call biographical incerpre the the systematic structure of his thought". I find this a helpful formulation. But I do not think it ex cludes the possibility of employing the notion of causation within biographical interpretation; and I doubt whether the arguments for an ideological account of Aristotle's theory of slavery presented in this paper would need much reformulation or revision if we tried to avoid thinking in terms of causation.

' Parekh, Marx's Theory of Ideology, 216.

- E.M. Wood and N. Wood, Class Ideology and Ancient Political Theory, Oxford 1978, 1. to combine in his analysis of an intellectual position diagnosis of social bias (cf. (i)) wit' a hypothesis about the reason for the bias that includes a non-cognitive component (cf. (ii)), applying in politics as elsewhere his maxim: "We must not only state the true view but also explain the false view" ( $E N H$ 14, 1154a 22-23). The proponents of democracy wrongly suppose that justice is nothing but equality, the partisans of oligarchy no less wrongly assume that it is simply a matter of recognising inequality. Why do both sides go wrong? Because people are bad judges in their own case (i.e. interest obtrudes), and because they take a partial notion absolutely (precisely the sort of cognitive mechanism Marx saw as characteristic of the ideological distorting effects likely to follow from occupying a particular position in the social nexus): especially for a rich man it is easy (but mistaken) to think that someone who is superior in (e.g.) wealth is superior in everything ( $P$ ol. $\Gamma 9,1280$ a 7-25).

But if Aristotle is uncommonly percipient in Book $\Gamma$, he may yet be vulgarly blind or partisan in Book $A$. After all, both parties to the disagreement about justice are made up of citizens: "us". What Book $A$ in effect does is define "them"-slaves, women, middlemen - from "our" vantagepoint. In other words, there is a possible origin-i.e. social motivation - for bias in the handling of the topics of Book $A$ which has no tendency to warp the treatment of justice in Book $\Gamma$

The blindness (cf. (ii) (a)) and parti pris (cf. (ii) (b)) characteristic of ideological belief are forms of false consciousness: someone holding such a belief will typically labour under a delusion or practise insincerity or both. In prosecuting the enquiry we shall find it useful to employ the category of false consciousness. But in asking whether Aristotle's theory of slavery is a product of false consciousness I assume that we shall not be concerned to be specific about which kind of falsehood-delusion or insincerity - might be in question.

What we shall find more helpful is a distinction suggested by the work of Raymond Geuss. In his book The Idea of a Critical Theory Geuss points out that there are different kinds of grounds on which one may attribute false consciousness to someone. Two of the three he distinguishes are of interest to us: consciousness may be ideologically false in virtue of some epistemic properties of the beliefs which are its constituents, or in virtue of some of its genetic properties.9 Epistemic vs. genetic is not a contrast we can take over without amendment, since (as Geuss's own treatment of the epistemic category makes clear) ${ }^{10}$ the falsehood in epistemic cases is in the end a matter of their origin or casual history, at least insofar as it is distinctively ideological. What Geuss's flawed taxonomy reminds us, however, is that, where we suspect a theory of being ideological, there are at least two different features of it which may give rise to the suspicion:

- R. Geuss, The Idea of a Critical Theory, Cambridge 1981, 13. I have found Geuss's book much the most penetrating treatment of the concept of ideology I have read.

10 The Idea of a Critical Theory, 69 (cf. 14). 
something about the nature, or more specifically the alleged epistemic status, of the theory itself, and something about the methods used in arriving at it.

Thus I first consider the method by which Aristotle reaches the concluThus I first consider the method by we himself sion that for certain sorts of men slavery is just and benoshical procedure, undoubtedly regards his method as a rational philosophical prejudices or undoubtedly rink that is largely a reflex of contemporary prejudices but we may think that is is lally the outcome of quite differthat his belief in the justice of slavery is really the outd be a case of false conent unavowed influences on his mind. This would be a case of fall theory sciousness which is deluded or insincere because the genesi

is quite other than what Aristotle represents it as bemic status. Geuss ex-

After methods we must turn to the issue of epistemic status. Geuss explains:

"By the 'epistemic properties' of a form of consciousness I mean such things as whether the not the descriptive beliefs contained in the form of consciousness aress is one in which not the descriptival evidence, or whether or not the form of consciousness is one in whe conbeliefs of different epistemic type (e. g. descriptive beliefs and normative beliefs) are confused."'11

There are three principal grounds on which one might convict AristotThere are three pring exhibiting epistemic properties characteristic of le's theory of slavery of exhibiting epistemic propers false consciousness. First, it may be argued that it suffers illegitimate objectification and generalisation. Aristotle takes the master- In reality this is not one grounded in nature and of benefit truth, but a projection of the interests an expression of objective, impartial truth, but a projection of theint among and activities of his own class. Second, it is a common complaint am and activities of his own idea of natural slavery is an anomaly within his scholars that Aristotle's idea of narusistent with his general theory of human psychology, and perhaps even internally inconsis mind of class inunlikely that the anomaly is due to the influence on his mination. ${ }^{12}$ Third, it might be granted argumenti causa that there are persons who satisfy totle's description of natural slaves, and even that slavl go $)^{13}$ it is a massive ate condition for such persons. But (the argument (for Aristotle, the conerror or pretence to assume that in the actual world (for Aristotle, the cain the temporary Greek world) slaves are what he calls natural slave

obvious explanation of the assumption is wishful thinking.

11 The Idea of a Critical Theory, 13

13. 12 For the idea that anomaly of this kind may prima to Terry Irwin.

vanced by a philosopher is ideological I am indebted to Terry

is I am grateful to John Cooper and Martha Nussbaum for pointion of ideology in Arission of this paper at Friedrichshafen that any treatment of the questi

sile's theory of slavery must come to grips with this argument.

\section{Aristotle's method}

It is easy enough to construct a case for the view that, however Aristotle himself may have thought that he had arrived at his belief in the justice of slavery, it was really little more than the reflex of ordinary Greek prejudices. For it seems likely that most unenslaved Greeks felt at ease with the institution of slave $y$. In Greek literature down to Aristotle there is precious little evidence of any unease, ${ }^{14}$ and it is notorious that Plato felt so little pressure to justify the institution in the Respublica that, as is apt to happen where servants are concerned, he barely bothered to acknowledge the unquestionable presence of slaves in his ideal state. ${ }^{15}$ The representation of slaves on painted pottery and in comedy, or again the attitude to slaves evidenced in Herodotus and Xenophon, makes it almost as likely that they were usually viewed as inferior, morally, intellectually, physically - whether because they were supposed racially inferior or for whatever reason (enslavement is not calculated to bring out the best in people). ${ }^{16}$ Why did unenslaved Greeks hold these views? It is hard to avoid the hypothesis of ideology, albeit a mostly inarticulate and undebated ideology ${ }^{17}$ (contrast the treatment of women): the durability and ubiquity of the institution in the ancient Mediterranean world will have made it difficult not to conceive it as part of the proper moral fabric of live, especially for those who had no obvious interest in envisaging any other possibility.

Aristotle makes it clear that his theory of natural slavery is designed to establish an ethical conclusion: "it is clear, then, that in some cases ${ }^{18}$ some are free by nature and others slaves: for whom slavery is both beneficial and just" (Pol.A 5, 1255 a 1-3). Is it not likely that this ethical proposition is something Aristotle accepted precisely because he too shared the gen-

14 There are the well-known remarks of Alcidamas: "God left all men free; nature made no one a slave" (schol. on Rh. A13,1373 b 18 in: Rabe (ed.), Commentaria in Aristotelem Graeca; Vol.XXI, pars II, Berlin 1894, 74); and of Philemon: "Even if someone is a slave, he has the same flesh; by nature no one was ever born a slave" (Fr. 39 ed. Meineke). They presumably reflect sophistic theory, no doubt the conventionalism about slavery mentioned by Aristotle at POL A 3,1253b20-23; i. something rather far removed from com-

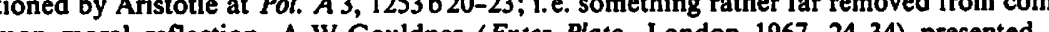
mon moral reflection. A.W. Gouldner (Enter Plato, London 1967, 24-34) presented a highly a priori argument for the existence of a general disquiet about slavery despite the silence of the sources, but does not seem to have convinced the scholarly world of his case. is See G. Vlastos, 'Does slavery exist in Plato's Republic?', in his Platonic Studies. Princeton 1973, ch.6. His conclusion is disputed by B.Calvert, 'Slavery in Plato's Republic', in CQ 37 (1987), 367-72, but I think unconvincingly. Calvert omits discussion of the crucial passage $R$. V $469 \mathrm{~B}-471 \mathrm{C}$

16 M. I. Finley, Ancient Slavery and Modern Ideology, London 1980, ch. III. See his illuminating discussion of Herodotus 4,1-4 (ibid., 118-19 in the Penguin edition, 1983). On Xenophon Oec. XII 18-19 see T. Wiedemann, Greek and Roman Slavery, London 1981, Xen.

17 It is already a drawback to the line of argument developed in this paragraph that it has to rely on the unsatisfactory notion of an inarticulate ideology: how could a body of ideas be inarticulate?

18 In other cases, presumably, enslavement may be contrary to nature: the cases alluded to at Pol. A6, 1255 b 4-5, and discussed at 1255 a $21 \mathrm{ff}$. 
eral Greek ideology of slavery, in consequence of the same causes as operated on Greeks in general? Why should he have been exempt from their influence? If he was not, then we should interpret the theory of natural slavery from which he deduces his ethical proposition not as the fundamental reason he has for holding the proposition (his acceptance of the ideology is what really causes him to hold it), but as an attempt to justify a belief to which he is already committed and had probably unconsciously absorbed in earliest boyhood. No doubt some elements in the justification articulate ideas other Greeks would readily have shared (e.g. the notion of the psychological inferiority of the natural slave), while others (e.g. the more general notion that all complex systems exhibit hierarchy, 1254a $24 \mathrm{ff}$.) are more special to Aristotle although not, or course, lacking in attraction. The key point, however, is that, while Aristotle derives his ethical justification of slavery as natural from these ideas, it is not they that explain his belief in the rightness of slavery but a more deep-seated acceptance of the popular ideology of slavery.

What might Aristotle have said in response to this diagnosis? One fundamental claim one would expect him to have wanted to make is that he is a philosopher and as such committed to examining by reason any question proposed for discussion. The assumption underlying such a response is that reason is a powerful source of insight-whether by virtue of its methods or of its scope-independent of common belief and ready to be critical of it. It is an assumption which itself gained the status of a communis opinio in Greek philosophical tradition from Heraclitus and Parmenides to Plato.

But if Aristotle shared it, he did so in such a deliberately qualified sense that it may well be doubted whether reason, as he envisages and employs it, can act as a significant counterweight to popular prejudice. The grounds for doubt are supplied by his famous endoxic method:19 the method has an elective affinity for ideology.

This thesis can be argued in a more or in a less straightforward version. The plainer version takes the endoxic method to embody the view (at least so far as ethics and politics are concerned) that common sense is what ultimately carries authority: reason can correct and refine it but never displace it or depart from it dramatically. It is at any rate very natural to read the celebrated statement of the endoxic method at $E N H 1,1145$ b 2-7 in this way:

"We must, as in the other cases, set the things that seem to be the case before us and, after first discussing the difficulties, 80 on to prove, if possible, the truth of all the reputable opinions about these affections [sc. continence, incontinence, etc.] or, failing this, of the greater number and the most authoritative, for if we both resolve the difficulties and leave the reputable opinions undisturbed, we shall have proved the case sufficiently."

19 See the classic discussion by G. E. L. Owen, 'tithenai ta phainomena', in: S. Mansion (ed). Aristotle et les problemes de méthode Louvain 1961, or most recently in: G.E.L Dialectic: collected papers in Greek philosophy, Mussbaum (ed.), London 1986.
Reputable opinions do not only constitute the starting-points and destination of enquiry. They guide it, as possessing an independent authority which it is the business of reason to confirm (if it can: we are in the realm

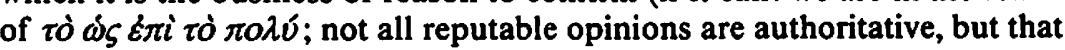
fact does not undermine the authority of those that are). Of course, Aristotle does not say here that the reputable opinions we should be attending to are mostly common or popular opinions (rather than those of the cognoscenti). But in . ethics and politics common opinions are what he usually has in mind. He is sometimes prepared to argue that common opinions carry weight because they rest on experience-on what over a long period of time has been found to work (cf. Pol.B 5, 1264 a 1-5, Div. Somn. 1, 462 b 14-16) as one would expect of a philosopher who lays such stress on the importance of experience in practical judgement. In fact the beliefs of the majority on matters of ethics and politics all too often constitute ideologies.

In recent years this interpretation of the endoxic method as an elaboration of common sense - at best conservative and at worst parochial - has been called in question by scholars. Barnes has pointed out that "there are remarkably few propositions which Aristotle cannot, in one way or an-

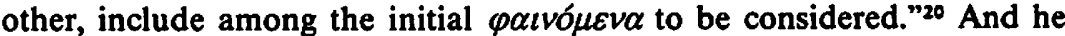
suggests that "the process of 'purification', generously construed, will allow him still greater scope in assembling" the most authoritative ones. $\mathrm{He}$ concludes:

"The method is not formally vacuous; but it has, in the last analysis, very little content."

Similarly Martha Nussbaum writes:

"The method does not make discoveries, radical departures, or sharp changes of position impossible, either in science or in ethics. What it does do is to explain to us how any radical or new view must commend itself to our attention: by giving evidence of its superior ability to integrate and organise features of our lived experience of the world." ${ }^{21}$

I am not persuaded by these revisionist accounts of the method. Barnes may be right that Aristotle's formulations of it are potentially elastic; and there are undoubtedly some texts where reason or argument is put firmly in the driving seat and the $\varphi \alpha t v o ́ \mu \varepsilon v \alpha$ relegated to provide supporting evidence and examples (so notably at EE A6, 1216 b 26-28). But at least when he wrote $E N H 1,1145$ b 2-7 Aristotle must have wanted to accord more weight to common opinion than that.

Whether the endoxic method is conservative or merely elastic it can of fer little resistance to popular ideology. Either way it fails to provide adequate stimulus to question whether what we take to be "our lived experience of the world" (e.g. "our" perception of slaves as inferior) is really experience, and even if it is, whether that experience might not be a func-

20 J. Barnes, 'Aristotle and the methods of ethics', in: Rev. Int. Phil. 34 (1980), 490-511 (at 510$)$.

21 M.C. Nussbaum, 'Saving Aristotle's appearances', in: M. Schofield and M.C. Nussbaum (edd.), Language and Logos, Cambridge 1982, 267-93, at 292. 
tion of social circumstances which could and conceivably should be different from what they are. The contrast with Plato is striking. Plato expects common beliefs and perceptions to be confused and erroneous, and claims a secure critical perspective from which to exhibit their deficiencies. The proof of the pudding is in the eating. In physics it is Plato who guesses that the elements require a mathematical analysis and are quite other than what appears. In politics, likewise, Plato is the thinker who takes a radical view of the polis, from the abolition of the family and the role of women to the education of rulers. Aristotle in these as in so many spheres sticks closer to the $\varphi \alpha \iota v \delta \mu \varepsilon v \alpha$ - as everyone would acknowledge. Is this not because the endoxic method is either conservative or anodyne? To be sure, the method accords reason a critical role. But Aristotle's discussions of the method leave that critical function theoretically underdescribed and indeed undernourished, so to speak. Is it any surprise that in practice its radical potential (which on a conservative interpretation of the method is in principle more limited in any case than Nussbaum would like) goes largely unrealised?

The endoxic method, then, leaves its practitioners all too prone to succumb to popular ideology.

This truth, however, does nothing to support the view that Aristotle's theory of slavery is ideology. As Victor Goldschmidt pointed out in an important article, Aristotle does not follow the canonical method of endoxa in his treatment of slavery. ${ }^{22}$ In Book $A$ of the Politica Aristotle (1) announces at the outset that he will pursue what is quite evidently an entirely different method: a method of analysis $(A 1,1252$ a 17-23); (2) follows this method in his discussions both of slavery and of household management ${ }^{23}$; (3) points out from time to time that he is following it $(A 3$, $1253 \mathrm{~b} 1-8 ; A 8,1256$ a $1-3 ; \mathrm{cf} . A 5,1254$ a $20 \mathrm{ff}){ }^{24}$ Most of the opinions of others on these topics that he cites in the course of the book he rejects as erroneous. ${ }^{25}$ For example, he refers dismissively to other views on slavery as ideas "that are nowadays supposed true" $(A 3,1253$ b 17-18). It is not in the least surprising that he shows no sign of using them as authoritative guides for investigation (which is what on the conservative reading of the endoxic method endoxa are supposed to be). All he attempts to do in this connection is to demonstrate with respect to some (not all) of the opinions he mentions that, with suitable reinterpretation, they can be harmonised with the account of the matter already established by the method of analysis. I suppose that, on an elastic understanding of the endoxic method,

22 V.Goldschmidt, 'La Théorie aristotélicienne de l'esclavage et sa méthode', in: Zetesis: Melanges E. de Strycker (Antwerp 1973), 147-63 (at 149-53).

${ }^{23}$ As is clearly shown for household management in Carlo Natali's paper 'Aristotle et la chrématistique' in the present volume.

${ }^{24}$ His attack on the issue of whether there are natural slaves is professedly launched not from endoxa but from argument or theory $(\tau \Phi \lambda \delta \gamma \omega)$ and the facts $(\varepsilon x \tau \omega v \gamma t v o \mu \varepsilon v \omega \nu)(A$ 5,1254 a 17-21).

${ }^{23}$ As Natali shows with respect to the discussion of household management. this demonstration might count as an application of the method. But the key thing to notice is that it is not the method which guides Aristotle's enquiry in Book $A$, but a confirmatory supplement to it. Aristotle himself was surely clear about the division of labour here, which is the same as in $E N A$, where at 8,1098 b 9-11 he bids us consider the question before us "in the light not only of our conclusion and of the premises of the argument, but also of the things that are said about it."26

Is the method of analysis any more resistant to ideology than the endoxic method? Potentially so, inasmuch as it involves an immediate appeal to reason $(A 5,1254$ a 20) and to first principles. And if the moral climate in which Aristotle grew up was unquestioningly complacent about slavery, his approach to the issue in the Politica shows him well aware that other thinkers rejected it as unnatural and unjust (this view is one of the ideas "that are nowadays supposed true": $A 3,1253$ b 20-23). There is clearly a sense in which he treats the question of the morality of slavery as an open one, to be settled by philosophy. ${ }^{27}$ Was he self-deceived or insincere in taking this line? The answer to that must largely depend on how powerful a piece of philosophical analysis Aristotle's is: the better it is, the more reason there will be to judge that it is philosophy, not the unavowed but deep-seated assumptions of his boyhood, which brings him to a belief in natural slavery. So it is time now to begin consideration of the more substantive arguments for the charge that the theory is ideology, not real philosophy.

\section{Nature and the projection of class interest}

We have learned to expect that ethical and political theories which appeal for their premisses to human nature will have created "nature" in the image of some contingent, historically situated and conditioned view of man. More particularly, the substitution of nature for history was diagnosed by Marx as a specially characteristic device of ideology:

"The ideologist 'justifies' the capitalist society on the ground that it alone is in harmony with human nature. He justifies hard work and attacks the demand for a relaxed social ex istence on the ground that scarcity is a natural human predicament. He explains overpopu-

\section{ard am gre}

26 I am grateful to Jacques Brunschwig, David Charles and Terry Irwin for helpful discussions about the endoxic method. Nothing I say about the method implies disagreement with the proposition that in Aristotle's view the first principles of philosophy - and so presumably the natural principles from which he derives his theories of slavery and house suld

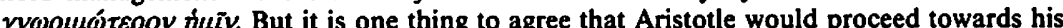
first principles dialectically, and quite another to maintain that that is what he is doing in Pol. $A$. He is not: in Pol. $A$ he is arguing from first principles.

27. My argument here is congruent with Finley's view (Democracy Ancient and Modern, London 1973, 66): “In ancient Greece, with its open exploitation of slaves and foreign sub jects, there would be little scope for ideology in the Marxist sense"; or again (Ancient Slavery and Modern Ideology, 117): "Ideological openness was facilitated by the nakedness of the oppression and exploitation: no 'false consciousness' was necessary or possible". 
lation as an 'inherent' tendency in man, and turns 'a social law into a law of nature'. He presents conflicts between individuals and groups as inherent in human nature and indeed in nature itself. He presents the socially created differences between men and women as natural, and argues that it is natural for women to be confined to homes or to less demanding jobs. He presents the historically created intellectual, moral and other inequalities between men as part of their 'natural endowment', and turns 'the consequences of society into the consequences of nature'. He argues that it is natural for social institutions to be hierarchically organised, for the intellectual skills to be better rewarded than the manual, and so on. As Marx frequently puts it, the ideologist 'eternalises' or 'deifies' a given social practice or order, and eliminates history."2u

Perhaps it seems prima facie unlikely that a great philosopher such as Aristotle could have fallen unwarily into the trap of simply assuming that what looks right or wrong must be natural or unnatural. Has any philosopher thought more or harder about nature? But Book $A$ of the Politica not only develops the theory of natural slavery, but takes for granted the naturalness of the subordination of women, and goes on to argue the unnaturalness of trade as a means of acquisition (in contı ast to agriculture, hunting, and direct exchange): all within the framework of a conception of the household, and of the polis itself, as natural. ${ }^{29}$ The longer the book goes on, the more insistent is the reader's suspicion that what Aristotle is really elaborating is the ideology of (or an ideology for) the affluent, slave-owning man of substance whom he sees as the ideal citizen of the polis. The claim that slavery is not only natural but beneficial to the slave only reinforces the diagnosis of false consciousness at work. The view that what is in the interest of a dominant class is in the interests of all is a notion even more highly characteristic of ideologies than the appeal to nature.

The complaint is that in Pol. $A$ Aristotle projects a particular actual form of society into a general norm. It is a complaint hard to evaluate. On the one hand, it is an attractive suggestion that the theory of slavery comes into proper perspective when we look at its context in Pol. $A$, and see it as just one item in a highly specific recipe for the good life for actual Greek "gentlemen". If you were an Athenian citizen of means, who regarded trade as a matter properly left in the hands of aliens (evidently the standard view), ${ }^{30}$ and considered the management of your own household your responsibility (not your wife's, as was often assumed in the fifth century), ${ }^{31}$ then Pol. $A$ would indeed give you a theoretical justification of what you already believed right and advantageous - but a justification which from our vantage point quite lacks the authority Aristotle's appeal

2* B. Parekh, Marx's Theory of Ideology, 137.

29 See e.g. G.E.R. Lloyd, Science, Folklore and Ideology, Part II, on women; on the household M. I. Finley, 'Aristotle and Economic Analysis', in: Past and Present 47 (1970) 3-25: S. Campese, 'Polis ed economia in Aristotele', in: D. Lanza and M. Vegetti (edd.) Aristotele e la crisi della politica. Naples 1977, 13-60. All these studies are in different ways alert to ideological dimensions of Aristotle's treatment of these topics.

30 See Finley's classic discussion (in: Past and Present 47 (1970), 3-25).

31 See again Carlo Natali's contribution to this volume. to nature seems designed to lend it. On the other hand, Aristotle is obviously attempting an intellectual project of universal validity. Its focus is man in general as social, autonomous agent, organising himself and those in his society who cannot organise themselves to secure what is needed by them all for the good life. The ideal Aristotle has in view is not far removed in general character from Marx's own vision of the society we will enjoy when man realises his potential for self-determined action and so for happiness. ${ }^{32}$ Nor is there anything necessarily ideological in thought about what human nature is capable of, or in the concern to secure a harmony of the interests of organiser and organised.

In short, we can come at Aristotle's views on slaves, women and trade from two directions: from contemporary Greek reality or from his own moral philosophy. If we adopt the first approach, an ideological explanation of these views seems well-nigh inevitable. But the second approach allows more scope for argument, and in particular it leaves open the possibility that we need a different story for what Aristotle says about slaves from what he says about women. False consciousness may have eaten its way unevenly into his thinking on these questions.

The key assumption Aristotle makes is that the grip of women and slaves on practical reason is such that they need to have their lives organised by others. He devotes very little energy to arguing this in the case of women. He takes it simply for a fact. And he is mistaken. The obvious reason for this male mistake is an inference from the pliableness of many women reinforced by contemporary social forms: a classic instance of false consciousness.

The treatment of slavery is quite different. It occupies the best part of five chapters of Pol. A. As we have seen, Aristotle begins by acknowledging that it is a controversial subject. And instead of accepting from the outset any "facts" about slaves, he so far reverses his normal procedure in scientific enquiry as to discuss first the question: "What is a slave?" before addressing the issue of whether there are any slaves properly so called. ${ }^{33}$ When he does address it, he works out his answer on the basis of very general considerations about the nature of animals in general and humans in particular. The kernel of his answer-that there are some people better off being ruled than ruling-is a not unreasonable thesis. Above all, at no stage in the central argument of Pol. A 4-7 is any use made of an assumption that most of those who in contemporary Greece were enslaved are natural slaves (indeed, the implication of $A 6$ is that some were unjustly enslavedthose who were slaves only in consequence of the fortunes and conventions of war). Rather the reverse: Aristotle's theory of natural slavery is at least potentially a critical theory. A slave owner who pondered it seriously would have to ask himself: "Is my slave really a natural slave? Or is he too shrewd and purposeful?".

32 See e. g. Stephen Lukes, Marxism and Morality, Oxford 1985, ch.5.

33 This point is well made by Goldschmidt, in: Zetesis, 149-53. 


\section{Anomaly and inconsistency}

Aristotle's theory of natural slavery is presented as an outwork of his general philosophy of man; it establishes a criterion of who is or is not suited to slavery against which actual cases of enslavement could be judged just or unjust; it is therefore not plausibly explained as ideology. So ran the argument of the previous paragraph. But it can be objected that the theory is in fact inconsistent with Aristotle's general account of man, and constitutes an anomaly within his system. If so, it may then be a sign of false consciousness at work that he advances a positive account of slavery at all.

The very idea that there could be natural slaves might be thought to conflict with a belief firmly rooted in Aristotle's general philosophy, viz. that man is an infima species with his own distinctive esse...e. His natural philosophy recognises no such species or sub-species as "ensouled tool". The conflict comes close to the surface when Aristotle discusses the question whether a master can enjoy friendship with a slave: insofar as he is a slave, no-for he is merely an ensouled tool; insofar as he is a man, yes-for he can partake in law and contract, and so justice, and so friendship (EN $\Theta 11,1161$ b 3-8). Aristotle's predilection for answering questions "yes and no" is often attractive, and he is often illuminating when he reflects on the different descriptions under which we identify one and the same item. Here the illumination is apparent enough, but the bland "yes and no" extremely uncomfortable. On Aristotle's own finding, "slave" and "man" must be incompatible designations, for the consequences of applying them to one and the same individual are contradictory. The air of compromise is quite bogus. ${ }^{34}$

Consider also the thesis that slavery is beneficial to the natural slave. Aristotle believes that slaves resemble women and children in being incapable of running their own or other people's lives: "the slave simply does not possess the faculty of deliberation [he perceives reason but does not have it]; the female has it, but in her it lacks authority; the child has it, but undeveloped" (Pol. $A$ 13, 1260 a 12-14; cf. $A$ 5, 1254 b 22-23). Like women and children, therefore, they need for their own safety to be ruled. For women leadership suffices, but what is right for children is a paternal rule (analogous to that of a monarch). The crucial feature of paternal rule is that its primary concern is the good of the ruled, not as with slavery the ruler's. Why is not paternalism equally the right way to treat the childlike who satisfy Aristotle's description of natural slaves? Is not their psychological condition so similar to children's as to make this the inescapable conclusion, and certainly the one most in their interests? Aristotle notor-

Aristotle is more willing to admit a real difficulty in connexion with the question of the virtue of slaves at Pol. $A 13,1259$ b 21-28. and his connexion with the question of strains within his account of slavery are well discussed by R. G. Mulgan, Aristotle's Political Theory, Oxford 1977, 40-4. iously takes a different line. Exploitation, not paternalism, is the order of the day. The childlike are just bodies, sentient tools; they will find more fulfilment in being used-in living out their function-than otherwise. Once again the premiss that some people are mere ensouled tools appears to conflict with more widely based tenets of Aristotle's philosophy, in this case his human psychology as adumbrated in Book $A$ of the Politica itself. Once again this premiss is what he requires to sustain a major doctrine about slavery, viz. that it is in the slave's interest. ${ }^{35}$

The use of the word "childlike" to designate those suited for slavery may appear to conceal an inconsistency of a different kind: one internal to the actual notion of the natural slave. There is much in Aristotle's account of slaves which suggests that they are feeble-minded and brutish They do not have reason but merely perceive it $(A 5,1254$ b 22-23); they are cut out primarily for physical labour, and indeed for the same sort of work as domesticated animals do $(1254 \mathrm{~b} \mathrm{12-34)}$. It is in virtue of just such features that their enslavement is held to be justifiable (cf. e.g. $A 2,1252$ a 30-34). But while this is the picture which emerges from the main argument in $A 5$ (with $A 2$ ), other comments made by Aristotle later in Pol.A point in another direction. $A 7$, which argues that masters are not masters in virtue of their possession of a relevant science, concedes that there are forms of knowledge appropriate both to masters and to slaves. Slaves can be taught their everyday duties of service, and (1255 b 25-30):

"This kind of instruction might well be extended to cookery and the rest of those kinds of service. For the tasks of the various slaves differ, some bringing more in the way of esteem, others being more in the nature of necessities. As the proverb has it: 'slave before slave, master before master' $"$.

$A 13$ adds that they require a form of virtue to withstand temptations which might impede performance of their jobs (1260 a 33-36), and consequently need not merely instructions but advice or encouragement (more so than children)-and must not therefore be denied reason (1260 b 5-7). Slaves such as these sound not in the least feeble-minded, but like the naturally slavish Asians $(\Gamma 14,1285$ a 16-22) who are said to be wellequipped for thinking and the skills (what they lack is spirit: $H 7,1327 \mathrm{~b}$ 27-29). It is hard to see why on the premises of $A 5$ they qualify as natural slaves at all.

How has Aristotle got himself into this difficulty? It is tempting to answer: because the ideological roots of his theory could not be concealed

ss I am obliged to Charles Kahn for forcing me to consider the issue raised in this paragraph, which I had neglected to do in the original version of the paper. My formulation of the problem is much indebted to N.D. Smith 'Aristotle's theory of natural slavery', in Phoenix 37 (1983), 109-22. The problem is, I think, crucially one about exploitation, awnership (1983), 109-22. The problem is, I think, crucially one about exploitation, not ownership: are there any humans whom we are justified in using as tools at will? Aristotle actually seems to hold that property simply consists in tools whose use one controls ( $A 4$, $1253 \mathrm{~b} 30-1254$ a 17). It is worth noting that the idea of treating other humans as tools need not itself be too troubling: Aristotle is prepared to think of friends in this way (EN $A$ 8, 1099 a 33-b 2). But friends are not like slaves at one's entire disposal. 
for long. In its initial presentation the theory may legitimate only very selective enslavement - of the feeble-minded. But the fact that Aristotle so soon slips in intelligent slaves who practise crafts, not just necessary physical tasks, shows that its real motivation was to justify the actual institution of slavery as he knew it. This hypothesis also suggests an explanation of the anomalous presence of the theory within his system: it is developed because class interest dictates that there should be slaves, not because it fits well with Aristotle's philosophy.

Yet appeal to ideology is not the only reasonable or intellectually respectable way of coping with anomaly and inconsistency. These are phenomena not unknown elsewhere in the writings of great philosophers. And there is at least one other commonly employed strategy for dealing with them: the exercise of interpretative charity. Perhaps that is what we should try in the present case, and hope to show either that thes inconsistencies are a sign of a fruitful tension within Aristotle's thought or that carefully considered they turn out not to be inconsistencies after all.

Let us take first the alleged inconsistency in Aristotle's treatment of the all-important issue of the psychology of the natural slave. There is a difficulty in supposing that Aristotle insincerely or self-deludingly forgets later in Book $A$ an earlier characterisation of natural slaves as essentially feeble-minded. The faculty in which they are from the outset declared deficient is deliberation or practical reason: the ability "to look ahead in thought" $(A$ 2, 1252 a 31-32). This - the power of deliberation - is once more denied them in $A 13(1260$ a 12). Hence their suitability for slavery: they need someone else to deliberate on their behalf if they are to survive (so e.g. $A$ 2, 1252 a 30-31). It is because they can follow deliberative reasoning in others $(A 5,1254 \mathrm{~b} 22)$ that they are accorded reason at the end of $A 13$ (1260 b 5-6); which does not conflict with its denial to them at 5 , $1254 \mathrm{~b} 23$-for they cannot deliberate themselves. Now this deliberative incapacity is not for Aristotle incompatible with the intelligent exercise of skills like cookery $(A 7,1255$ b 26$)$ or shoemaking $(A 13,1260$ b 2$)$ : children too acquire such skills without thereby achieving the consistency of purpose and the breadth of reflection needed to look after themselves properly; and it is the comparison with children that Aristotle dwells on most in $A$ 13. It would be at odds with the doctrine that slaves cannot deliberate to suggest that they might exercise the architectonic skills of farmmanagers or bankers. But Aristotle does not suggest any such thing.

In $A 2$ and 5 he certainly gives the impression that brute physical strength and deliberative incapacity are two sides of a single coin, and together supply the rationale of the slave's symbiotic relation with his master. This emphasis on the physical is best seen as expository exaggeration, not unlike the stress put upon habituation of the passions in the initial account of moral virtue in $E N B$, where in order to distance himself from the Socratic identification of virtue with knowledge Aristotle notoriously underplays the role he himself assigns to rational judgement. Maybe the childlike adults of Pol. $A$ are usually physically robust, but Aristotle him- self observes that this is often not the case (A 5, $1254 \mathrm{~b} \mathrm{32-1255} \mathrm{al})$. We should allow him a similar $\omega_{\zeta} \varepsilon \pi i \tau \dot{\delta} \pi 0 \lambda v$ with regard to the necessary tasks they are fitted to perform: some may be capable of more that the bare essentials, without significantly altering the general Calibanesque picture, and without moving into the ranks of those who can deliberate.

Aristotle's conception of the psychology of the childlike adult may therefore be seen as a reasonably coherent one, accommodating the possibility of the intelligent exercise of a range of skills. Is the further claim that this psychology equips him to be a living tool similarly defensible within the context of Aristotle's general philosophy of man against the objections we raised? In $A 13$ Aristotle himself formulates an ämogía which bears directly on the problem. Does the slave have a virtue (e.g. any of the moral virtues) of greater worth than excellence in service? If yes, how will

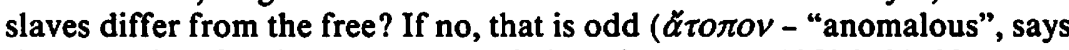
the Penguin), for they are men and share in reason (1259 b 21-28).

The resolution Aristotle offers $(1260$ a 14-24; 1260 a 33-36) in effect denies the assumption which the $\dot{\alpha} \pi \circ \rho^{\prime} \alpha$ comes close to enunciating, viz. that the categories of living tool and human being are incompatible. The excellence of a slave is certainly the fine service of a living tool. But such service will require the exercise of the moral virtues only humans can possess: courage, temperance and the rest. For without a little of them the slave may fail in his function. He does not need (for example) the administrative courage of a general or statesman, but "subordinate courage" ( $\delta \pi \eta \rho \varepsilon \tau \kappa\rangle \dot{\alpha} \alpha \varepsilon \tau \tau)$ to cope with the dangers of the job.36

So "living tool" is not the name for a distinct species (or pseudo-species) of animal. It is a way of describing a perfectly recognisable sort of human being, so as to pick out what Aristotle regards as the distinguishing mode of activity appropriate to their childlike, but often physically robust, condition.

We might still believe that the correct way to treat such persons is paternalism, not exploitation. It is not clear that we would be right. At any rate Aristotle supplies some materials for an argument to the contrary. The crucial difference, he might say, between a child and a natural slave is that the child can and normally will acquire strategic purposes of his own (even if at present his capacity for deliberation is very undeveloped), but the natural slave never can. This difference may reasonably suggest a difference in rule. We should treat children in such a way as to encourage their development as independent agents. The childlike are best off if prescribed a sensible programme of short-term activities which serve our own

36 Mulgan (Aristotle's Political Theory, 42) observes: "If the slave can be expected to act virtuously even to this extent, he must be capable of independent action and not confined to blind obedience to his master's orders". He seems to think this is inconsistent with Aris. totle's view of what a slave is. But we see no incompatibility in recognising capacities in a totle's view of what a slave is. But we see no incompatibility in recognising capacities in a
sheep-dog for independent action in its work with the sheep, while at the same time holdsheep-dog for independent action in its work with the sheep, while at the same time hold-
ing that its function in life is to help its master herd sheep (without itself possessing any sort of strategic deliberative powers). 
purposes (as it might be, cooking the lunch, then hoeing the turnips, and then sweeping the yard), since they will never be in a position to construct a programme (or at any rate a satisfying sequence of programmes) of their own. That way they will share in our life and so have some participation in a full human life, with the possibility of friendship of a sort $(A 6,1255 \mathrm{~b}$ $12-15)^{37}$ and the attainment of a kind of excellence (with the self-respect and satisfaction that brings). ${ }^{38}$ The only obvious alternative is a passive existence punctuated by desultory activity with no particular purposes at all, as is the fate of many of those we commit to paternalistic institutions (not noted for the liberalism of their regimes) in contemporary civilised societies.

But it is one thing to argue that the doctrine of living tools is a defensible piece of Aristotelian philosophy. It is quite another to understand why Aristotle should have wanted to advance it at all. Until we have a puilosophical explanation of that, it will remain very natural to continue to suspect ideological motivation.

\section{Slavery and the argument of the Politica}

Why does Aristotle include a discussion of slavery in the Politica in the first place? This question is harder to answer than one might expect. For example, it is tempting to suppose that Aristotle's main object in Book $A$ is to establish that the polis is a natural community; that in order to show this he argues that political life is the fulfilment of a desire for self-sufficiency which finds its first expression in the less developed but no less natural community of the household; and that the need to show that the household is a natural community is what leads him to present at some length a vigorous case for the naturalness of one of its two fundamental component relationships-slavery. (It is then something of a puzzle why he does not supply more argument for the naturalness of marriage, the other basic element in the household, especially given the attack on it in the Respublica. ${ }^{39}$ ) But although Aristotle does not always make the

"Aristotle would, of course, need to improve on his account in $E N \Theta 11,1161$ b 3-8 of what makes such friendship-evidently taken to be a form of advantage friendship - psychologically possible. But there is no reason to think the task impossible or even very difficult. What Aristotle has to avoid is the inference: if $x$ is a living tool of $y, x$ is not the friend of $y$ (which he appears to accept in the Ethics). That should be easy enough, since it does not look a very plausible inference. Moreover if life for $x$ involves some rudimentary form of reason (such that $x$ can say, for in retur for (such that $x$ can say, for in return for my services"), then we could presumably conclude from the living tool premiss that $x$ might be the friend of $y$. In the Ethics passage Aristotle gives too much weight to "tool" in constructing his inference; but Pol. $A 13$ shows that he has seen that he has to ponder the consequences of "living" (1260 a 33-36).

32 The treatment of the virtue of slaves in Pol. $A 13$ would seem to make a revision necessary in Aristotle's claim ( $E N K$ 6,1177 a 8-11) that happiness is not possible for a slave.

"He does, of course, attack Plato's theory in B 2-4, but makes surprisingly little play strategy and organisation of the argument of Book $A$ as explicit as he might have done, it seems probable that his main preoccupation is not the naturalness of the polis and its constituent associations - which is a topic barely mentioned in subsequent parts of the treatise. The issue which appears to dominate his mind right through the book is the question: how many forms of rule $(\dot{\alpha} \rho x \hat{\eta})$ are there? And the urge to reply: "not just one but several" is the mainspring of the argument. 40

This problem about rule is raised right at the beginning of Book $A$, in ch. 1 (1252 a 7-16):

"It is an error to suppose, as some do, that the roles of a political leader, of a king, of a householder and of a master of slaves are the same, on the ground that they differ not in kind but only in the numbers they rule. For example, they think someone who rules a few is a cules still more a is a master, some who a political leader or a king, as if there, were no differ, ance bu small polis. As to the difference between a political leader and a king, they suppose that when someone is in personal control, he is a king, but when he takes his turn at ruling and being ruled according to the principles of the science they have been specifying, he is a
political leader. But these views are false."

The author of the error is not named, but Aristotle's immediate target is clearly a passage in Plato's Politicus (258 E ff.) which asserts the identities Aristotle denies. What lies behind Plato's thesis is the idea that ruling is essentially a form of knowledge or science $(\dot{\varepsilon} \pi l \sigma \tau \dot{\eta} \mu \eta)$, and he takes the characteristic Socratic and Platonic view that whether you rule as a king or as a politician, it is one and the same science that you should practice: so despite obvious differences of scale (house vs. city) or constitutional system (monarchy vs. a political form of government) it is one and the same man - the expert in ruling - who is in every case the proper person to exercise rule. Aristotle does not make it clear in $A 1$ what he most objects to in Plato's account, although later in the book $(A 3,1253 \mathrm{~b} 18 \mathrm{ff}$.; $A 7$, $1255 \mathrm{~b} 20 \mathrm{ff}$.) he is contemptuous of the idea that being a master is essentially a matter of science at all - it rather consists in a superiority of powers (and pre-eminence in excellence or virtue, incidentally, is probably what he would say was the key feature which distinguishes or should distinguish a king from a politician). He does suggest immediately, however, that the inadequacy of Plato's position follows ( $\gamma \alpha$ ó: 1252 a 9) from the initial characterisation of the polis as the most important kind of commu-

with the naturalness of marriage there. He has more to say on the subject at $E N \Theta 12$, 1162a 16-33.

40 My argument for this interpretation has much in common with that developed in $\mathrm{C}$. Natistele', in: Polis 3.1 (1979-80), 2-18. H. Kelsen has the main point, although distorted by his preoccupation (1979-80), 2-18. H. Kelsen he the main point, although distor' in: J.Barnes al (edd) "Aristotle and Hellenic-Macedonian Policy", in: J.Barnes et al. (edd.), Articles on Aristotle vol. II, London 1977, 170-94, at 172-5. He well says: "The whole presentation of the slave problem in this first book of the Politics is rather of a political than of an economic character".

41 I adapt the revised Penguin translation (T. A. Sinclair, revised by T.J.Saunders, Harmondsworth 1981). 
nity, which encompasses all others. The fact of its inadequacy, he goes on (1252a 17-23), will become plain if one analyses the polis into its elements. Then we shall see why the roles he has introduced into the discussion differ from each other, and perhaps achieve some expert understand. ing with respect to each of them. The job of analysis is duly undertaken in ch.2, where Aristotle develops his argument for natural growth of the polis from the household.

That argument, therefore, is launched with a view to refuting Plato's unitarian conception of rule. How it accomplishes this purpose is not spelled out by Aristotle. But the moral does not need much teasing out. The rule of a master is a primitive form of rule, as kingship is the primitive form of government in a state, and it is to be contrasted with what is appropriate to the perfected community of the polis; the rule of a master is concerned only with subsistence, politics with the good life. These differences do not in themselves formally disprove Plato's identity thesis. Aristotle must suppose that they are so massive as to make it very implausible.

When he turns to give extended treatment to slavery, he stresses his interest in it as a system of "necessary use" or "essential service", and also the need to achieve a better understanding of it than is supplied by the Platonic identity thesis $(A 3,1253$ b 14-20). In $A$ 5, his argument that there is such a thing as natural slavery, he first claims that there is in animals something (the soul) whose nature is to rule and something (the body) whose nature is to be ruled (1254 a 28-36). From this he moves straight to the proposition that we can see already in animals the rule of a master and political rule-and see that they are different: the soul is master of the body, but reason exercises political or kingly rule over desire (1254b 2-6). Again, after he has completed his statement of the theory of natural slavery and discussed alternative views, he proposes that it is now evident that the rule of master and political rule are not the same. The one is exercised as a monarchy (cf. $A 2,1252 \mathrm{~b} 19-24$ ) over natural slaves, the other is government of those naturally free and equal $(A 7,1255 \mathrm{~b} 16-20)$. Nor is the rule of a master a matter of science (contrast political rule [EN $A 2 ; K$ 9]): someone is a master in virtue of being a person of a certain sort, not because he has a certain kind of skill (Pol. A 7,1255b 20ff.). The digression on acquisition then intervenes. On his return to discussion of the proper functions of household management in $A 12$ and 13 it is once again the difference between forms of rule which engrosses Aristotle. In particular, $A 13$ is a sustained exploration of the sorts of moral excellence that are within the reach of those whose nature it is to be ruled in accordance with one or other of the different forms of rule identified in the examination of the household.

In $A 12$ Aristotle begins by reminding us of the three "parts" of the household: master and slave, husband and wife, father and children (cf. $A$ $3,1253 \mathrm{~b} \mathrm{4-12)}$. The job of household management is to exercise the different sorts of rule appropriate to each of these different relationships -it is not just a matter of directing the slaves: the householder has to rule free persons, his wife and children, as well (1259 a 37-40). The rest of the chapter is devoted to substantiating the thesis that rule over a wife is different from rule over children. In the one case (wives) the political analogy is political rule, in the other (children) it is kingship, for wives need leadership like one's peers, whereas children are junior and not yet fully developed (1259 a 40-b 4). What one might have expected, given the claim of $A$ 2 that the polis grows naturally from the household, is some attempt to exploit the political analogy in service of that claim, particularly since elsewhere Aristotle makes a great deal of the parallels in the structure of authority in the household and in the polis. Both Ethics take the same line ( $E E H$ 9, 1241b 27 ff.; cf. $E N \Theta 10,1160$ b 23-1161 a 9):

"All forms of constitution exist together in the household, both the correct forms and the All forms of constitution exist together in in constitutions as in the case of musical deviations (for the same thing is found in constitutions as in the case of musical modes)-paternal authority being royal, the relationship of man and wife aristocratic, that of brothers a republic, while the deviation - forms of these are tyrar
democracy; and there are therefore as many varieties of justice" 4 .

And both suggest that the household already contains the blueprint or even the seeds of political forms of organisation: "resemblances to these -indeed, a sort of pattern of them - can also be found in households" ( $E N$ $\Theta 10,1160 \mathrm{~b} \mathrm{23)}$; "hence in the household are first found the origins and springs of ... political organisation" ( $E E H 10,1242$ a 40 ). This style of thought would have well suited the argument of $A$ 2. But Aristotle is apparently not interested in pressing his argument about the household in that direction. My guess is that he has come to feel the schematic analysis of the Ethics texts too artificial, and too concerned to interpret the household in terms of the polis; and he has of course in a sense located the seeds of the different forms of rule elsewhere-in the psychological structure of the individual ( $P O L$. $A$ 5 1254b 2-23; $A$ 13, 1260a 9-14). In any event what we can discern in Pol. $A 12$ and 13 is a greater preoccupation than is perceptible in the Ethics with the different forms of natural rule found in the household, and with their ethical consequences (EE $H 10$ had in fact talked as though "natural rule" was a univocal notion [1242a $34 ; 1242$ b 28], effectively equivalent to "paternal rule").

The dissimilarity of the master-slave relation from other forms of rule, then, and especially from political rule, is the focus of Book $A$ in general and of the treatment of slavery in particular. Aristotle introduces discussion of the master-slave relation at a number of later places in the Politica. His interest in doing so is once again to distinguish political rule from the rule of the master. Thus in $\Gamma 4$ he argues that political rule is something one learns by being ruled (like military command), whereas the master does not need to learn the "necessities" which are the job of the slave, only how to make use of them (1277 a 25-b 13 ; cf. $A 7,1255$ b 20-35). $\Gamma 6$ holds that the rule of a natural master is essentially concerned with the interest of the ruler, only accidentally with that of the ruled, whereas in

42 I cite the Loeb translation of H. Rackham (revised edition, 1952). 
politics, like household management, rule is exercised either for the good of those ruled or for the common interest (1278 b 32-1279 a 21 ; cf. $H 14$, 1333 a 3-11). Aristotle indicates that the distinction is one he has frequently made in the $\varepsilon \xi \omega \tau \varepsilon \rho t x o i$ iórot: it is not only the Politica that weaves slavery into this pattern of thinking.

Perhaps the most interesting of all the subsequent appearances of the theme occurs in $H 2$ and 3, where it plays a part in the discussion of the relative claims of the active or political life and a private and inactive life. The passage needs to be read in its entirety. Suffice to say that Aristotle is particularly anxious to expose a premiss which he thinks is shared both by those who reject the political life, even though they have a concern for virtue, and by many who admire it, precisely because they have no qualms about committing injustice. Their common mistake is to suppose as "the many" do $(H 2,1324 \mathrm{~b} 32)$ that the rule of a master (or in this context despotism) and political rule are one and the same thing, or that all rule is the rule of masters $(2,1325$ a $27 \mathrm{f}$.). This is what leads the virtuous to stay out of politics: from their false premiss they infer (and would be right to infer) the false conclusion that political life is no life for a free man-for there is nothing impressive in using other people as slaves. It is equally what attracts many people to politics: they have no compunction about dominating (or trying to dominate) neighbouring states contrary to justice, and indeed think domination over others is what brings happiness $(H 3$, 1325 a $16-27 ; H 2,1324$ b $1-22$ ).

Aristotle presents this immoral attitude as a popular one $(H 2,1324 \mathrm{~b}$ $32 \mathrm{ff}$.$) , and of course we are put in mind of Callicles and Thrasymachus$ and of what Glaucon and Adeimantus represent as the common view of justice; or again of the Athenians' line of argument in the Melian dialogue. Aristotle himself associates it with "all the nations that have the power to aggrandise themselves" - the Scyths, the Persians, the Thracians, the Celts (1324 b 9-12) - and above all with the Spartans (1324 b 5-9), whose whole system of government is geared to war and conquest, and who do not realise that rule over free men is nobler than despotism and more connected with virtue $(H 14,1333$ b 5-35). Its popularity is no doubt one reason why he is so concerned to undermine the equation of domination and political rule which underlies it. Perhaps it also does something to explain why he gives the attack on Plato's unity thesis such a fundamental strategic role in Book $A$. Plato's view of all rule as essentially a single form of knowledge does not necessarily entail immoralist consequences. But its obliteration of crucial distinctions is dangerous, for it is just such $\alpha \pi \alpha \iota \delta \varepsilon v \sigma i a$ that Realpolitik will exploit with a vengeance.

\section{Concluding Unscientific Postscript}

Except in the context of his preoccupation with the different forms of rule, Aristotle betrays only a very occasional passing interest in slavery in the Politica. It is therefore reasonable to expect that this preoccupation will supply us with a vantage point from which to see in proper perspective the problematical features of his theory.

There have to be distinct forms of rule, according to Aristotle, because there is a great variety of deliberative capacities among humans. This makes an equivalent variety appropriate in the kinds of rule exercised over them. Aristotle thus avoids having to lay down by fiat his prize thesis that political rule is quite different from despotism and that the one is the right system for a properly thriving human society, the other illegitimate. His distinctions are to be objectively grounded in the nature of things - or rather, of human beings. We modern liberals might have hoped that within this general intellectual framework he would have concluded: some forms of rule are natural, but slavery is unnatural. What he is working with, however, is not a bare division (natural-unnatural), but the richer concept of natural hierarchy. In a hierarchical scheme it was no doubt very tempting to make slavery not something unnatural but the extreme case in a range of cases of natural rule. Certainly it was reasonable to try to identify a specific form of rule appropriate to the childlike.

Does Aristotle's postulation of a natural basis for the difference between slavery and political rule require him to take any stand on contemporary slavery? Does he need to ask whether the slaves in the society of his day were natural slaves? Clearly not. And, of course, he does not ask the question. The most economical explanation of the fact that he does not is precisely that it is not a question immediately pertinent to his argument about forms of rule: his concern is with the essential character of the master-slave relation, not with slavery as it actually was in fourth-century Greece.43

Unfortunately that is not all that can and should be said about Aristotle's view of contemporary slavery. While his argument does not require him to take a stand on slavery as it actually was in his day, there are points at which he gratuitously expresses or betrays an unargued attitude towards it. The evidence is pretty straightforward. Most Athenian slaves (so the historians tell us) were "barbarians". And Aristotle seems pretty much wedded to the racist idea that barbarians (otherwise Asians) are naturally slavish $(A 2,1252$ b $7-9 ; \Gamma 14,1285$ a 16-22; $H$ 7, 1327 b 27-29), despite having some fun at the expense of double-thinking Greeks who justify enslavement of foreigners by insisting that, although some of them may be well-born, they are so "only at home" $(A 6,1255$ a $32 \mathrm{ff}$.). There is no avoiding the conclusion that more or less unthinkingly Aristotle accepted that most slaves in his own society were natural slaves. No doubt his as-

43 One might have expected that the tacit question motivating Aristotle's theory of slavery was: "Why is slavery so prevalent everywhere?", and that the doctrine of the natural slave was offered as the best explanation of that phenomenon: "Because it is natural." (I am grateful to Julia Annas and Christoph Eucken for pressing this possibility on my attenam grateful to Julia Annas and Christoph Eucken for pressing this possibility on my atten-
tion.) The argument of section 5 , however, supplies not only an alternative motivation but one that is much better supported in the text. 
sumption is to be explained in ideological terms, as due ultimately to the bias we might expect in a slave-owning culture which looks outside its own borders and ethnic identity for its supply of slaves. ${ }^{.4}$

This is a nasty case of false consciousness. But it does not infect Aristotle's theory of slavery itself. In working out his theory he does not make the supposition that he is describing contemporary slavery or even that what he is saying is applicable to it. The theory does not explicitly or otherwise pretend to be a theory directly or indirectly concerned with contemporary slavery. The false consciousness gets to work when Aristotle stops theorising.

There is a sort of insulation of theory from reality in Pol. A. Aristotle surprisingly does not consider it part of his job as theorist of slavery to comment on existing practice. So when he does allow himself the luxury of an opinion, unsurprisingly it turns out to be uncritical. We have here the same kind of disjunction between thought and practice as is evident in Aristotle's will, which provides that some of his slaves be given their freedom (Diogenes Laertius 5, 14-15). It would be unconvincing to suppose that these were natural slaves. Aristotle simply failed to allow his theory of ownership to exert any pressure on his own practice while he lived. ${ }^{4}$

These are human enough failings. They constitute a form of false consciousness distinct from those identified by Geuss: a sin of omission rather than commission, and a familiar version of trahison des clercs. ${ }^{46}$

4 The acquisition of natural slaves by war is defended as naturally just at Pol. $A 8$, 256b 23-26 (cf. $A 7,1255 \mathrm{~b} 37-39$ ). Aristotle talks there as though he has in mind campaigns - "hunts" - against specifically targeted groups or communities, no doubt "barbar" com "ho "there are some primitive that the natural incapacity of the forms of community so primitive that the natural incapacity of their members for genuine deliberation is thereby apparent to a civilised visitor." I am grateful to Geoffrey Lloyd for drawing attention to the ideological dimensions of this text. Its theme is also the subject of some interesting remarks by Stephen Clark, 'Slaves and Citizens', in: Philosophy 60 (1985) 27-46, at 32-6 (cf. also his Aristolle's Man, Oxford 1975, 106-7), and of a fascinating discussion of a sixteenth century controversy by Anthony Pagden, 'The School of Salamanca' and the 'Affair of the Indies,' in: History of Universities 1 (1981), 71-112, or more expansively in his book The Fall of Natural Man, Cambridge 1982.

is It is true that at $H 10,1330$ a $23-33$ he recommends that in the best constitution farm workers will if possible be slaves, and the "itt is better to hold out the prospect of freedom as a prize to all slaves." This latter provision has sometim been thought to confict with his view that slavery is beneficial for the natural slave, and indeed better for him than freedom. Clearly it does not. All it implies is that natural slaves would usually prefer to be free. That being so, they are more likely to cooperate and to work hard if promised their freedom: that is why it is better to hold out the prospect -better for masters. (I owe this in terpretation of this text to Myles Burnyeat.)

46 This paper has (I trust) benefited greatly from the discussion at the Symposium. I have tried to list my main individual debts to symposiasts at the appropriate points in the che to scrap some parts of the original version while retaining others, and made me see wher needed to argue a lot harder. Myles Burnyeat kindly read a penultimate draft. The final

\section{Appendix: The argument of Pol. A 6}

In $A 3,1253$ b 20-23 Aristotle gives a brief indication of a view of slavery which is the very opposite of his own:

"Others say that it is contrary to nature to rule as master over slave, because the distinction between slave and free is one of convention only, and in nature there is no difference, so that this form of rule is based on force and is therefore not just."

He refers to this thesis in the same disparaging terms which he uses of the false Platonic doctrine he has just mentioned (to the effect that being a master is a sort of science, 1253 b 18-20): it is one of "the things that is nowadays supposed true" (1253 b 17-18). Does he subsequently discuss this conventionalist view of slavery?

At the beginning of ch. 6 it certainly looks as though he is going to. $\mathrm{Ch} .5$ has ended with the words: "It is clear, then, that in some cases some are free by nature and others slaves: for whom slavery is both beneficial and just" ( $A$ 5, 1254 b $39-1255$ a 2 ). Ch. 6 begins with what must surely be a reference to the conventionalist view: "But it is not difficult to see that those who say the opposite are in a way correct to do so" (1255 a 3-4). For the opposite view is presumably that no one is naturally free or slave, and slavery is accordingly unjust, which is precisely what the conventionalist of ch. 3 maintained.

The next lines of ch.6 (1255 a 4-7) confirm that it is indeed the conventionalist position Aristotle has in mind. But they also make it clear that he is not going to concern himself with the position as it is conceived by its authors (i.e. by the philosophers referred to at $A 3,1253$ b 20-23):

"For to be in slavery and slave are said in two ways. For there is also someone who is a

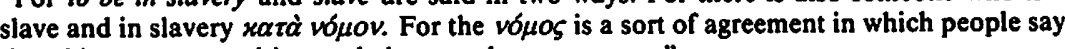
that things conquered in war belong to the conquerors."

The reference to vó $\mu$ os makes it impossible not to think of conventionalism. The diagnosis of two senses of "slave," the implication that the slave by convention is only one sort of slave, and the restriction of conventional slavery to a category covering only those taken in war are all signs that Aristotle has not the least intention of taking conventionalism seriously as a quite general account of what the basis of slavery is. In effect he is saying: "Chapters 4 and 5 showed that conventionalism is false. But we can extract a useful point from it. Some of those called slaves are slaves only as a result of the conventions of war; and such persons are unjustly enslaved." If there were any doubts about this interpretation, the last paragraph of the chapter should allay them ( $A$ 6, 1255 b 4-15). Here Aristotle shifts the focus from what is just to what is beneficial (cf. 1255 a 3), and concludes that where slavery is natural it is beneficial to both master and slave, but the opposite if it is based on convention and force.

In the intervening passage (1255 a $7-$ b 4), which takes up most of the

versions of sections 4 and 6 have been much influenced by discussion with him. It is more than usually necessary for the author to take sole responsibility for the outcome. 
space and nearly all of Aristotle's ingenuity in the chapter, we are given the actual arguments for the proposition that conventional slavery is unjust. Aristotle proceeds by attacking the contrary thesis, that it is just. But it takes him quite a while to get to the point (at 1255 a $21 \mathrm{ff}$.), because he is struck by what is evidently to him a much more interesting thought: that the premisses people are or would be prepared to appeal to in debating this issue betray a commitment to the idea that those superior in virtue should rule and be masters (1255 a 20-21; 1255 a 39 - b 1)-as being the natural thing (1255 a 29-32; cf. 1255 b $1-4)$.

The train of thought from 1255 a 7-21 is particularly intricate, and interpretation is complicated by a textual issue. Aristotle begins by implying

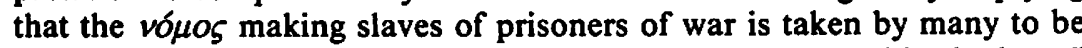
something just, and then reports that many of those "versed in the laws," on the other hand, reject it (or rather its claim to justice) as "unconstitutional," so to speak. Their argument is that it would be a dreadful thing if all that was enough to make someone a slave (or in general a subject) were the application of superior force. The reasoning behind this is presumably that the general body of laws do not recognise seizure by force as a valid claim to ownership.

There is a similar disagreement, says Aristotle, among philosophers: $\tau \varpi \nu \sigma o \varphi \omega \nu$. One might expect it to be a disagreement about conventional or legal slavery, but it is pretty clear that it is a more general dispute about whether rule based on force is just. (And from 1255 a 17-19 we can identify the two parties to the dispute as Callicles and Thrasymachus.) The reason for the disagreement, we are told, is a shared premiss which provides an element of overlap between the arguments on the two sides: "force is not without virtue"-there is something admirable and excellent and profitable about it. Why does this premiss explain the existence of a debate on the question? Aristotle does not say. Presumably his thought is: if there were nothing admirable about force, then everybody would reject rule based on force as unjust; it is because there is thought to be something good about it that a dispute develops.

Given that both sides agree that "force is not without virtue," it must be something else that they disagree about. Aristotle identifies this as "only justice." I think the context suggests that he means to imply "merely justice": these thinkers have a high regard for force and its virtues-but do not care much about justice. At 1255 a $17-19$ it is explained that each derives from the shared premiss about force $(\delta i \grave{\alpha} \tau o v \tau o)$ a different conclusion about justice. One party (Thrasymachus's: PI., $R$. I $348 \mathrm{C}$ ) considers justice to be nothing but stupidity, ${ }^{1}$ as standing in the way of exercising

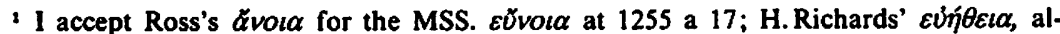
though implausible as a conjecture, has the merit of drawing attention to the Respublica passage Aristotle must have in mind. Against orvorc: (1) So far as I know no Greek philopopher ever identifies justice with goodwill. (2) Ir Aristotle intended something weaker the virtue inherent in force, and therefore, no doubt, they would be willing to say that rule based on force alone is unjust (with the implication: who in their right mind will be troubled at that?). The other party (Callicles': Gorgias $483 \mathrm{D}$ ) retains the positive evaluation associated with the word "justice," but radically transforms its content: justice simply is the principle that the stronger should rule. The rule of force becomes just by definition. ${ }^{2}$

Now follows a difficult Ėzí in Aristotle's text (Pol.A 6, 1255 a 19). I take him to be adducing in conclusion a reason for supposing what has hitherto been merely asserted, that Callicles' and Thrasymachus' arguments do indeed share a premiss, viz. the premiss he has specified:

"Since although these arguments stand quite apart from each other [sc. they do represen very different views of the justice of rule by force], there is no strength or persuasivenes [sc. so far as Callicles or Thrasymachus is concerned] in the arguments on the other side, to the effect that the superior in virtue should not rule or be a master [i.e. the arguments which in effect deny the shared premiss]."

The disagreement between Callicles and Thrasymachus explored at 1255 a 11-21 turns out to be something of a digression from Aristotle's main theme, which is the question of the justice of conventional or legal slavery. It is not only that their dispute is about the broader topic of rule by force in general, but its grounds are quite different from those Aristotle seems to indicate in what he says about slavery at 1255 a $6-11$. Those who consider conventional slavery unjust do so because they think it shocking that people should be enslaved by force: Callicles and Thrasymachus are agreed that dominating others by force is admirable. Aristotle himself does not take sides in their controversy, evidently because he finds their shared premiss repugnant: but he makes it absolutely clear that in the ar-

\&vev: 1255 a 15-16). (3) Aristotle elsewhere associates goodwill with friendship, never mentioning justice (e.8. EN $\Theta 2,1155$ b $27-1156$ a $5 ; 15,1166$ b $30-1167$ a 21). He is, of course, in favour of goodwill, but he does not think all that much of it: $800 d$ ill (167 a 11). Goldschmidt (Zetesis, 155) cites Democritus Fr.

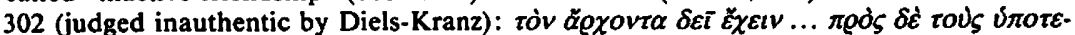

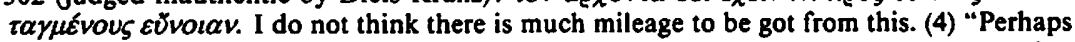
Aristotle means that the element of justice here (i.e. in the enforced enslavement) consists

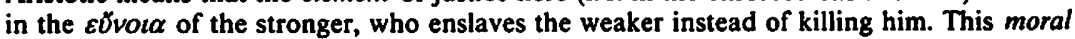
superiority gives him a right to be the master." But 1255 a 13-16 give the impression that it is the use of force itself which is associated with virtue by these thinkers, not restraint in its use. (5) It is hard to understand why the doctrine that justice is good will should be conceived as any sort of consequence of the idea that "force is not without virtue". Newman (The Politics of Aristotle vol II, Oxford 1887, 156) interprets thus: "One side argues from ter and slave, slavery is just only where there is good will between master and slave, and that consequently the indiscriminate enslavement of those conquered in war is unjust". This makes the doctrine about goodwill entirely independent of the premiss about force (although Newman accepts that $\delta t \alpha$ tovto (1255 a 17) refers to that premiss); nor is the conclusion about the conditions of justice for slavery in any way a consequence of the premiss.

2 Cf. D.J. Furley, 'Antiphon's case against justice' in: G. B. Kerferd (ed.), The Sophists and their Legacy, Wiesbaden 1981, 81-2. 


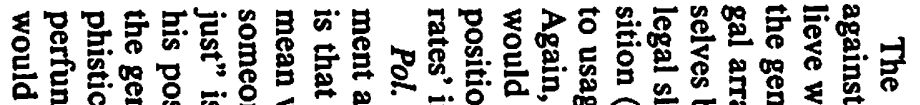

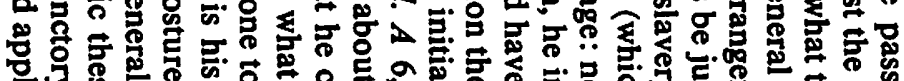

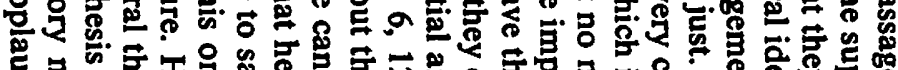

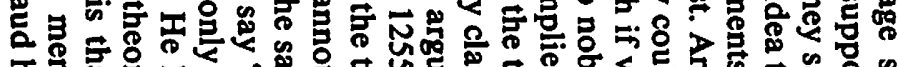

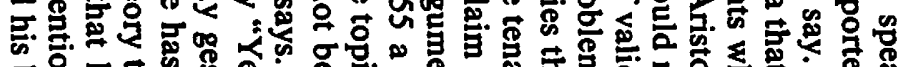

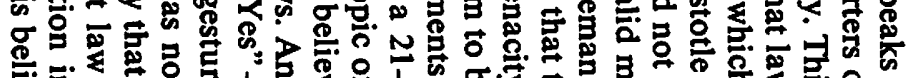

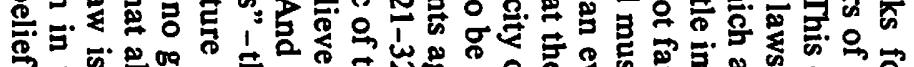

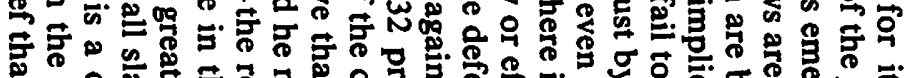

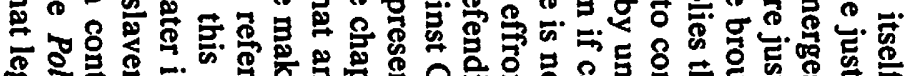

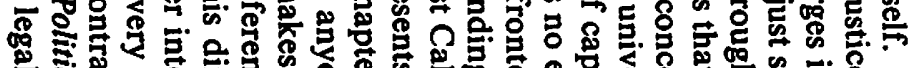

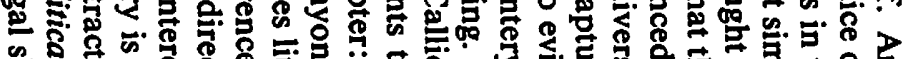
象

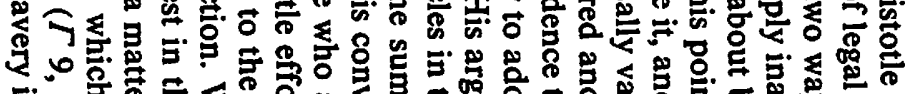

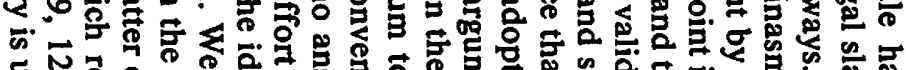

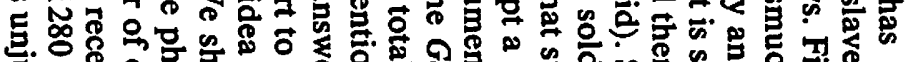

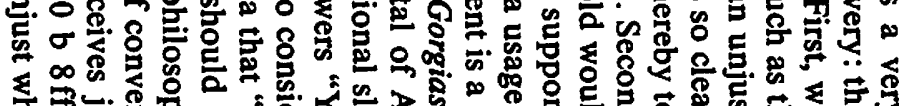

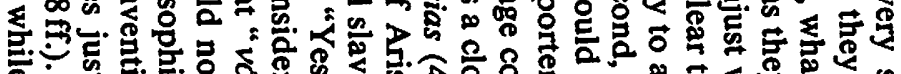

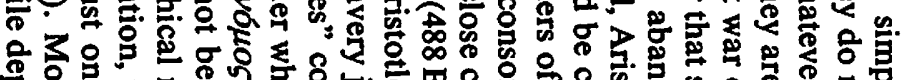

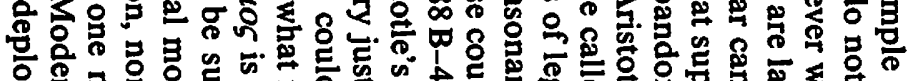

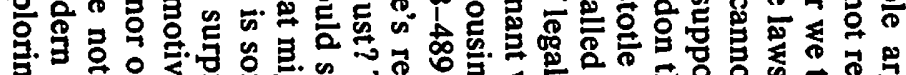

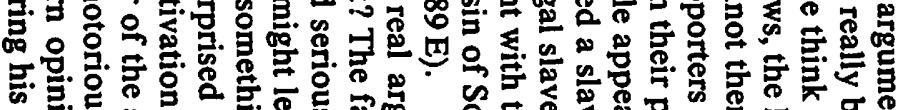

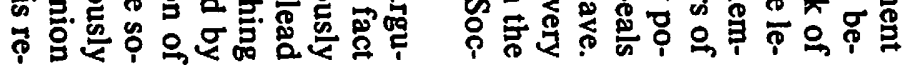

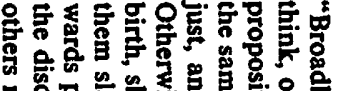

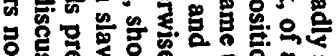

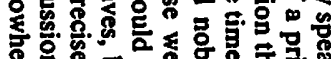

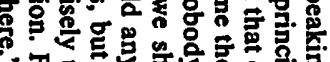
: 궁

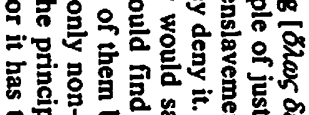

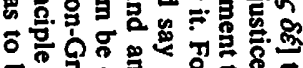

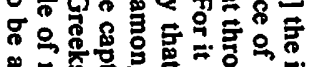

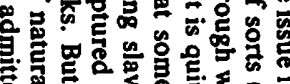

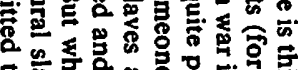

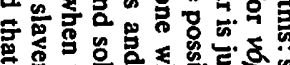

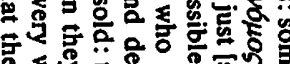

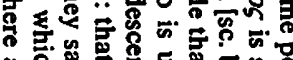

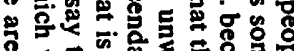

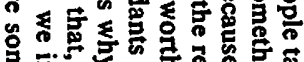

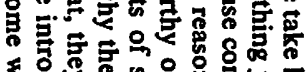

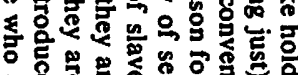

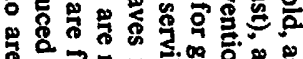

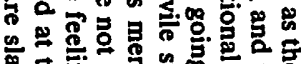

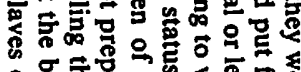

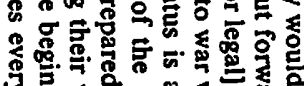

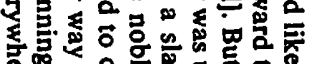

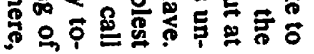

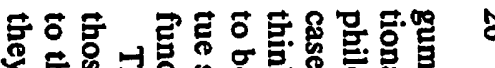

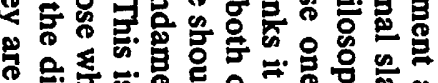

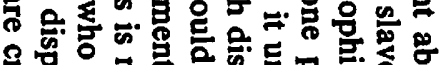

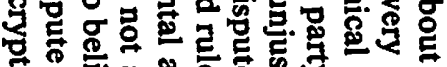

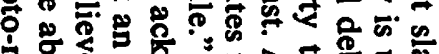

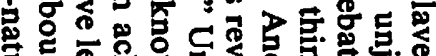

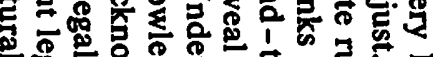

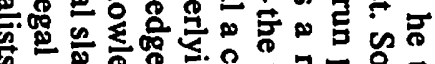

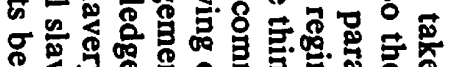

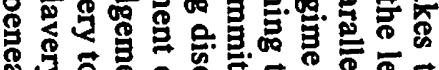

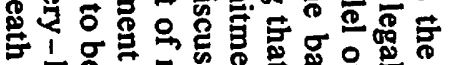

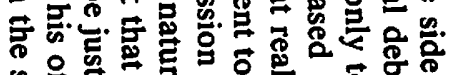

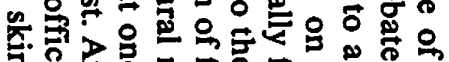

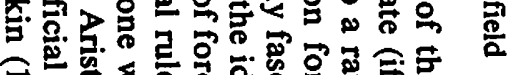

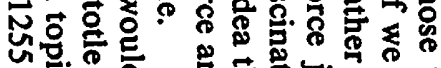

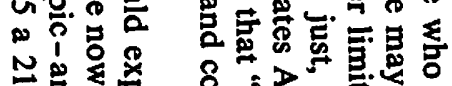

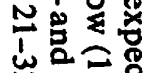

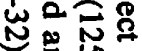

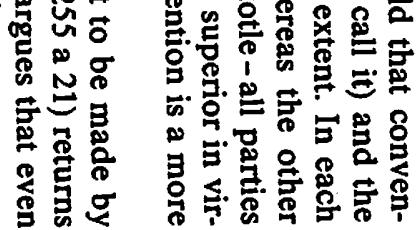




\section{СH. H. KAHN}

\section{Comments on M.Schofield}

Malcolm's stimulating discussion of the issue of ideology obliges us to consider anew the connections between Aristotle's theory of slavery and the rest of his political philosophy. I think Malcolm is right to take the question of ideology so seriously here, where we are dealing with the most embarrassing stretch of argument in the whole corpus. I refer briefly to what seem to me the most positive contributions of Malcolm's paper, and then discuss some points of disagreement.

The central claims of the paper, as I see it, are 1) that the focus of Book $A$ is not on the naturalness of slavery or the naturalness of the state but on the more fundamental idea of natural rule, and 2) that Aristotle's major concern here is to show that natural rule is not a unified. concept but one that takes different forms. Leaving aside for a moment the question of ideology, we can agree that the second claim incorporates an important insight, which connects the theory of Book $A$ in an essential way with Books $\Delta-E$. This explains why Aristotle opens Book $A$ with an attack on the Platonic view that assimilates political rule to despotic, monarchical and household forms of governance. That is not petty polemic, as I had supposed, but a clue to the fundamental concern of Book $A$ : how many different kinds of rule are there?

There was some difference of opinion among the symposiasts at Friedrichshafen as to whether the concept of ideology can do honest work in the history of philosophy. Clearly, the term is often used simply as a weapon to discredit philosophy that the speaker dislikes. But it is equally clear in the case of some arguments and theories, for example in support of racial or sexual inequality, that although they are presented as rational considerations based upon moral principle or even as scientific conclusions from experimental data, they must also be seen as politically motivated defences of social or political inequalities. This is not a claim about the psychology of the author so much as a factual observation about the political tendency, and foreseeable consequences, of such theory and such research. Not all studies that emphasize differences between groups fall under this suspicion, only those that tend to justify inequalities of power and privilege. Now of theories that $d o$ lend themselves to such suspicion, few if any can rival Aristotle's defense of slavery. For here we are given philosophical grounds that claim to justify the naked exploitation of man by man. If Aristotle's theory of slavery does not count as a case of ideology, it is hard to imagine that any seriously argued philosophical doctrine could ever qualify for this description.

In reply to Malcolm's defence of Aristotle against this charge, I would begin by challenging the proposed definition of ideology in terms of the causation of belief. In the first place, such a definition seems inapplicable to historical texts. Belief is a psychological concept, and Aristotle's psy- chology is not accessible to us. We cannot possibly know how far he was motivated by a desire (perhaps unconscious) to rationalize the system of which he and other members of his class were beneficiaries. But there is a more fundamental objection to this approach to the concept of ideology. Even in contemporary instances where we can ask someone what he or she believes, or infer belief from behavior, the notion of causation does not apply to beliefs in any clearcut way. It is true that, according to a fashionable view, beliefs are causes of action; but what are the causes of belief? We speak obscurely but inevitably of "influence" here, where it is a question of explaining someone's intellectual stance. I very much doubt whether the obscurity that surrounds this idea of intellectual influence can be elucidated by means of the notion of causality. In introducing the issue of ideology. I would take a quite different tack.

What is at stake here is a problem in the theory of interpretation. How are we to explain or make sense of a given political doctrine? I suggest that we think of ideology as identifying one particular mode of the more general approach that we may call biographical interpretation, that is, an interpretation that refers to the life and experience of the author rather than to the logic of his arguments and the systematic structure of his thought. The general question is: when is it appropriate to interpret a doctrine in biographical terms rather than in terms of the internal logic and structure of the text? The more specific question of ideology is: when should a biographical explanation refer not to the individual features of an author's experience but rather to the general outlook and interests of his class, his social position, his gender prejudices, or similar considerations that reflect the facts of social power and privilege? As a rough general answer $I$ suggest the following. An ideological interpretation is appropriate when the following conditions hold: (I) the doctrine in question does in fact tend to justify such social interests and (II) the doctrine exhibits one or more of the three following features: (a) it rests upon assumptions that seem arbitrary or implausible, (b) it is supported by unusually bad arguments, and (c) it conflicts with other fundamental principles held by the same philosopher. The last three conditions (II a-c) reflect the failure of a strictly internal, philosophical exegesis and thus establish the basis for an external, biographical explanation. ${ }^{1}$

Condition I specifies when an external interpretation qualifies as ideological. Does Aristotle's defence of slavery in fact tend to justify the position of power and privilege enjoyed not only by slave-owners but by all free men (and women) in a slave-owning society? I originally thought there was no need argue this point. But by emphasizing the contrast between the theory of natural slavery and the facts of contemporary practice, Malcolm now suggests that Aristotle's doctrine "is at least potentially

1 This identifies one legitimate function of a biographical interpretation: to account for the production of bad philosophy by a good philosopher. But I do not mean to imply that this is the only, or even the chief function of biographical interpretation. 
a critical theory. A slave owner who pondered it seriously would have to ask himself: 'Is my slave really a natural slave? Or is he too shrewd and purposeful?"' (11). Certainly many contemporary slaves will not have exhibited the intellectual deficiencies that characterize Aristotle's natural slave. And the legitimacy of enslaving captives in war seems to be similarly undermined by Aristotle's treatment of this claim in Pol. A6. So could it be a mistake after all to regard Aristotle's theory as a justification of contemporary slavery?

It is true that, since Aristotle insists that slavery based only upon violence or convention is not natural and not advantageous to both parties (1255 b 14-15), he implicitly recognizes that much actual slavery is unjust. But that is not where the weight of his argument falls. His thesis is a claim of naturalness as far as the institution is concerned: the master-slave relation represents one form of natural rule. What Aristotle argues for is neither the justice nor injustice of contemporary practice but the rightness of the institution. Despite all its qualifications, Aristotle's theory is a defence of slavery as such, in a theoretical context where that institution had been brought under attack. Aristotle certainly exercises the philosopher's privilege of criticizing what he regards as irrational in contemporary thought and practice. But he does not regard the institution of slavery as irrational. Since the existence of the institution clearly serves the social and economic interests of the non-slave population, I conclude that condition $I$ is satisfied.

What about conditions II a-c? Does the theory rest on arbitrary assumptions? Is it supported by strikingly bad arguments? And does it harmonize with other basic principles in Aristotle's philosophy? Let us take a look at the text.

Aristotle's basic argument is that whenever a group of people differ from others "as much as the soul differs from the body and a man from a beast", then the latter are slaves by nature and "it is both advantageous and just for them to be slaves" ( $A$ 5, 1254b 16-20; $A$ 5, 1255 a 1-3). There are three claims here: (1) Some people are naturally inferior to this extent (as he says later, they lack the capacity for deliberation); (2) it is just for them to be ruled by their superior; and (3) it is in their interest to be so ruled. And there is a further claim made in the definition of the slave as "living possession", a kind of tool or instrument who belongs "wholly to the master" ( $A$ 2,1253 a 32; $A$ 4,1254 a 10-13); for this implies (4) that the relationship exists for the sake of the master, and not for the sake of the slave. (So explicitly later, $\Gamma 6,1278 \mathrm{~b} 35$.) Now if we assume for the moment that (1) is satisfied, that there really are some humans who are by nature unable to make rational decisions for themselves, we might agree that (2) and (3) would follow: it would be in their interest (and hence presumably just) for them to be controlled and cared for by others. This is the kind of argument for paternalism that seems quite plausible in the case of the feeble-minded or the mentally unstable. But it surely does not follow that they should be the chattel or tools of their keepers, or that it would be in their interest to toil for the sake of others with sound minds. The claim that it is the slave's interest to belong wholly to the master seems grotesque; and Aristotle's argument for it is quite specious (the slave is a part of the master, and the interest of a part is the same as the interest of the whole, $A 6,1255 \mathrm{~b} 10$ ).

The weakness of the argument here only underlines the extraordinary nature of the assumption: that some humans might lack an essential feature of rationality so that they differ in kind from other humans "as much as a man differs from a beast". It is hard to state this assumption without self-contradiction. For Aristotle, the distinctive feature of human kind is precisely our rationality, our possession of logos, as he has so eloquently argued in Pol. A 2. The claim now that the natural slave "shares in logos to the extent of perceiving but not possessing it" ( $A 5,1254 \mathrm{~b} 22)$ emerges as an arbitrary thesis, required by his argument but apparently incompatible with Aristotle's own theory of human nature.

I conclude that the defence of slavery satisfies all the conditions for ideology. It obviously serves a class interest by justifying a system of gross inequality; it is supported by a painfully bad argument, which takes as its premise the assumption of a difference in kind among humans that conflicts with one of the fundamental principles of Aristotle's own philosophy. The importance of Aristotle's commitment to the defence of institutionalized inequality will emerge more clearly if we consider the class structure for the "best constitution" which he outlines in Book $H$ (chs. 8-9). When we compare this with the class structure of Plato's Respublica, we see that Aristotle has unified Plato's two upper classes (rulers and soldiers) and assigned to them the property which Plato reserved for the third class, the mass of citizens. In Aristotle's scheme this third class, the bulk of the population, are no longer citizens at all; they are only necessary conditions, not parts of the $\pi 0 \lambda \iota \tau \varepsilon i \alpha$. In other words Plato's farmers and artisans have not only been disenfranchised, they have been enslaved: their labor serves to support the leisure of the ruling class. And in this utopian construction Aristotle makes no claim to be concerned with the interests of the subject population. He considers only how they can best perform their work and be least likely to revolt (Pol. $H 10,1330$ a 25-33). His suggestion there that all slaves should be offered their freedom as a possible reward does not sit comfortably with a sincere belief in the doctrine of natural slavery. At the very least, this remark reveals Aristotle's recognition that even natural slaves cannot always be expected to appreciate the advantages of their condition.

Above all, the role played by the subject population in the best constitution shows that Aristotle's political theory involves more than an "occasional passing interest in slavery" (20). The institution of slavery is the foundation on which Aristotle would build the good society. 

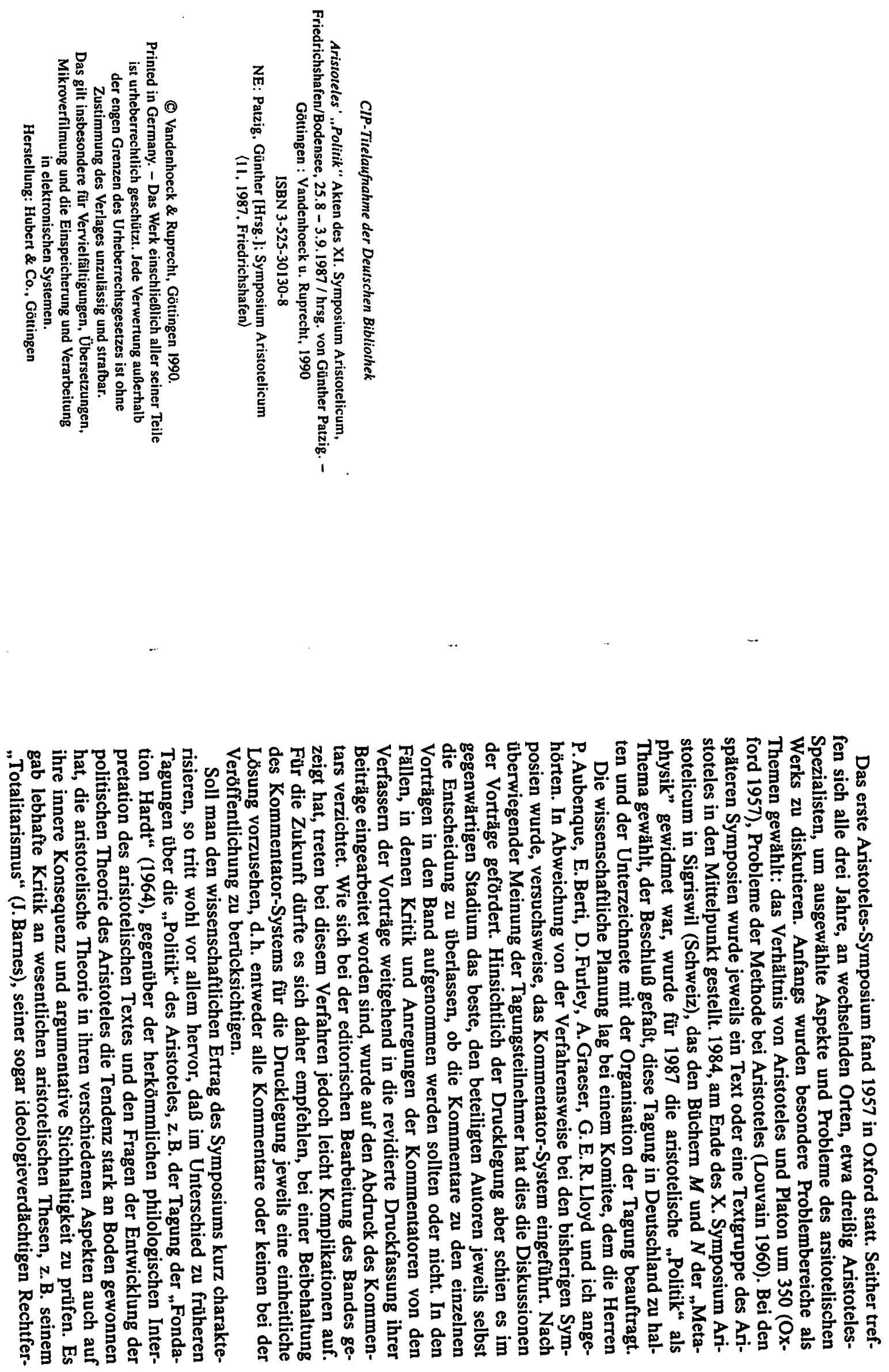